\title{
Dissemination of wine-related yeasts by migratory birds
}

\author{
Nicola Francesca, ${ }^{1}$ Domenica E. Canale, ${ }^{2}$ \\ Luca Settanni ${ }^{1}$ and Giancarlo Moschetti ${ }^{1 *}$ \\ ${ }^{1}$ DEMETRA Department, Viale delle Scienze 4, 90128, \\ Palermo, Italy. \\ ${ }^{2}$ Department of Animal Biology, University of Palermo, \\ Via Archirafi 18, 90123, Palermo, Italy.
}

\section{Summary}

The present work was undertaken to evaluate the contribution of migratory birds in the environmental dissemination of yeasts. Four sites (Mazara del Vallo, Lampedusa, Ustica and Linosa), representing the main stop-over points in Sicily, were analysed during spring and autumnal bird migration and 349 birds (belonging to 10 families) were ringed and analysed for yeast presence. A total of $\mathbf{1 2 5}$ yeasts were isolated and identified by a multiple genotypic approach, consisting of restriction fragment length polymorphism (RFLP) of 5.8S rRNA gene and 26S rRNA and sequencing of D1/D2 domain of the 26S rRNA gene, which resulted in the recognition of 18 species, including the technological relevant Saccharomyces cerevisiae which were characterized at strain level applying three techniques (interdelta analysis, minisatellite analysis based on the separate amplification of three genes and microsatellite multiplex PCR of polymorphic microsatellite loci). The evaluation of the persistence of living S. cerevisiae in birds for about $12 \mathrm{~h}$ from ingestion of inoculated feed allowed the conclusion that yeasts with technological potential are disseminated during migration.

\section{Introduction}

The microbial habitat associated with birds represents the object of several ecological surveys (Maul et al., 2005). The interest towards these investigations is on the increase for the evaluation of the health state and/or risk of diseases of birds (Silvanose et al., 2001), but especially to deepen the knowledge about the human infections associated with wild birds (Omenn, 2010). Free-living birds, including migratory species, have been

Received 21 September, 2011; accepted 27 October, 2011. *For correspondence. E-mail giancarlo.moschetti@unipa.it; Tel. (+39) 091 23896050; Fax (+39) 0916515531.

(C) 2011 Society for Applied Microbiology and Blackwell Publishing Ltd reported as long-distance vectors of microorganisms that can be transmissible to humans (Nuttall, 1997). Indeed, associations between wild birds and microorganisms have been studied mainly focusing on bacteria, whereas limited studies on yeasts are available (Cafarchia et al., 2006).

The monitoring of bird movements allows the investigation about behavioural and demographical responses to a given environment (Burton et al., 2006). The migration of birds includes a round trip to the resting areas and a return to the territories of nesting, which occur in autumn and spring respectively. These movements follow the seasonality of food resources. The main energy source during flight is the body fat. The birds with low fat reserves have the necessity of stopping in some resting sites (stop-over) along the route. The phenomenon of migration is typical in the islands of the Mediterranean Sea where birds stop to increase fat lost during flight.

Since birds act as microorganism vectors, the analysis of the microflora they host may be important to evaluate the microbial diversity of the sites visited. From the application perspective, yeasts carried out by birds have not been deeply investigated. Nowadays, there is a growing interest of wine producers to perform winemaking employing 'autochthonous' strains which may ensure typical terroir characteristics (Terroir Viticoles, 2006). At this regard, Francesca and colleagues (2010) recently reported on the dissemination of oenological yeasts by vineyard inhabiting birds, mainly Black birds (Turdus merula), although no yeast with technological relevant traits was found in the few migratory birds analysed. Those authors evidenced an issue related to the autochthonous status of yeasts, since they may not be indigenous in a given environment. The species Saccharomyces cerevisiae represents the most important oenological yeast, whose origin is quite hard to retrieve (Naumov, 1996; Mortimer, 2000). This species is not an air-borne contaminant and needs a vector (Mortimer and Polsinelli, 1999).

Yeasts may be transported at different distances depending on the vector. Some studies provided evidences that insects such as honey bees disseminate S. cerevisiae strains at a distance of approximately $10 \mathrm{~km}$ (Goddard et al., 2010), thus the investigation of migratory birds may better clarify the movements of yeasts with technological relevance. During migration, several sites 
are visited by birds because they represent important stop-over points. In case of migration from Africa to Europe and vice versa, Lampedusa and Ustica are visited in spring when the direction is from sub-Saharan areas to North Europe, while Linosa and Mazara del Vallo are visited in autumn when the movement is opposite (Svensson, 1992).

For the above reasons, the main aims of the present work were: to evaluate the potential of birds in disseminating yeasts at long distances, analysing the main migration stop-over points in the Mediterranen Sea (1, Riserva Naturale Integrale Lago Preola and Gorghi Tondi - Mazara del Vallo; 2, Lampedusa island; 3, Ustica island; and 4, Linosa island); to identify yeast species; and to determine the permanence of yeasts in birds after ingestion.

\section{Results and discussion}

\section{Characterization of the sites}

The four experimental sites located within Sicily region (Riserva Naturale Integrale Lago Preola and Gorghi Tondi, Lampedusa island, Ustica island and Linosa island) and the period (spring and autumnal seasons) for bird collection were strategic for the evaluation of the role of several birds in the dissemination of yeasts through North Africa and Europe. The experimental procedure included the collection of samples in the first stop-over points visited during each migration. In order to avoid any contamination of birds with local materials, the capture has been performed in the proximity of the woody areas in each site of ringing just at the moment of landing. The sampling size could not be designed because affected by species (and /or individuals per species) variability.

In the present study, 349 birds were captured (Table 1). All birds were quickly ringed, identified at species level by phenotypic analysis (Mullarney et al., 1999), classified according to their migration strategy (trans-saharan or partial) (Svensson, 1992) and subjected to visual biometric measurement of subcutaneous fat amount (SFA) of the abdominal region (Kaiser, 1993). The body fat is the first energy source dissipated by birds during migration and when SFA reaches a value of 0 or 1 , a stop is necessary (Goymann et al., 2010).

\section{Isolation and identification of yeasts}

Yeasts were isolated from bird cloacae, where they have reasonably arrived after gastric transit. Hence, the primary source of yeast contamination has to be imputable to the food ingested.

Yeast presence was found in $32.66 \%$ of birds (Table 1 ) that was a higher percentage of yeast isolation than that reported by Cafarchia and colleagues (2006) who analy- sed a similar number of birds (421). The bird families showing the highest frequencies of isolation were Muscicapidae, Passerideae and Turdidae and except the birds belonging to the Fringillidae and Passerideae families, which are insectivores in spring and granivorous in autumn, all other birds captured in this study are obligate insectivores (Snow and Perrins, 1998).

The process of isolation resulted in the collection of 125 yeasts, which were genetically identified. After restriction analysis of 5.8S-ITS region, the isolates were clustered in 18 groups; eight of these groups were recognized at species level (Aureobasidium pullulans, Candida albicans, Cryptococcus magnus, Debaryomyces hansenii, Hanseniaspora guillermondii, Pichia terricola, Metschnikowia pulcherrima and Rhodotorula mucilaginosa) but 10 were not. They were characterized by atypical restriction profiles of 5.8S-ITS that is not surprising, since many authors observed this behaviour in several yeasts (Fernandez-Espinar et al., 2000; Kurtzman and Robnett, 2003; Solieri et al., 2007; Tofalo et al., 2009).

Yeast identification continued with 26S rRNA gene digestion which confirmed the 18 groups, but identified less species then the previous methods, included in the eight above cited. Moreover, the identification at species level was concluded by sequencing of the D1/D2 domain of the 26S rRNA gene, which was successful for 17 out of the 18 groups (Table 2). Yeasts of group $\mathrm{V}$ were only recognized at genus level, since a low percentage (95\%) of identity was found with Candida spp. An even lower similarity level $(92 \%)$ with the same genus was obtained from the sequencing of the region 5.8S-ITS (Acc. No. JF292448). It is worth of note that the digestion products obtained from ITS fragment of group III (Candida glabrata), IV (Candida inconspicua), V (Candida spp.), VI (Candida stellimalicola), VII (Cryptococcus aureus), VIII (Cryptococcus carnescens), XII (Pichia kudriavzevii), XV (Pseudozyma aphidis), XVII (S. cerevisiae) and XVIII (Sporisorium penniseti) have not been previously reported in literature.

The yeast species most frequently encountered during isolation (Table 3) were $H$. guilliermondii (17.60\%), C. albicans (16.00\%), S. cerevisiae (14.40\%) and A. pullulans (12.00\%). Among the yeast isolates, 72 belonged to species that are commonly reported to be wine-associated (WA) yeasts such as A. pullulans, D. hansenii, H. guilliermondii, $P$. kudriavzevii, P. terricola, M. pulcherrima, R. mucilaginosa and $S$. cerevisiae (Loureiro and MalfeitoFerreira, 2003; Gonzalez-Pombo et al., 2008; Moreira et al., 2008; Francesca et al., 2010; Ocón et al., 2010).

\section{Bird/yeast correlations}

The distribution of yeasts among birds is reported in Table 3. The highest number of species and isolates were found for the bird groups most numerous. Thus, garden 
Table 1. Bird captured ${ }^{a}$ in four Sicilian ringing sites.

\begin{tabular}{|c|c|c|c|c|c|c|}
\hline \multirow[b]{2}{*}{ Bird family } & \multirow[b]{2}{*}{ Bird species } & \multirow{2}{*}{$\begin{array}{l}\text { No. of } \\
\text { birds }\end{array}$} & \multirow{2}{*}{$\begin{array}{l}\text { No. of birds } \\
\text { carrying } \\
\text { yeasts }\end{array}$} & \multicolumn{2}{|c|}{$\begin{array}{l}\text { SFA }{ }^{b} \text { of birds } \\
\text { carrying yeasts }\end{array}$} & \multirow[b]{2}{*}{ Sampling sites ${ }^{c}$ (number of birds) } \\
\hline & & & & $0-1$ & $2-7$ & \\
\hline \multirow[t]{15}{*}{ Sylviidae } & Sylvia borin (garden warbler) & 90 & 41 & 26 & 15 & L (5); Ln (6); MdV (4); U (26) \\
\hline & Sylvia curruca (lesser whitethroat) & 1 & 0 & 0 & 0 & \\
\hline & Hippolais polyglotta (melodious warbler) & 1 & 0 & 0 & 0 & \\
\hline & Hippolais icterina (icterine warbler) & 24 & 8 & 6 & 2 & $\mathrm{~L}(2) ; \mathrm{U}(6)$ \\
\hline & Acrocephalus scirpaceus (reed warbler) & 12 & 5 & 1 & 4 & MdV (4); U (1) \\
\hline & Acrocephalus arundinaceus (great-reed warbler) & 3 & 0 & 0 & 0 & \\
\hline & Sylvia atricapilla (blackcap) & 2 & 1 & 1 & 0 & $\operatorname{Ln}(1)$ \\
\hline & Acrocephalus schoenobaenus (sedge warbler) & 6 & 3 & 3 & 0 & $\mathrm{~L}(3)$ \\
\hline & Phylloscopus trochilus (willow warbler) & 7 & 4 & 0 & 4 & $\operatorname{Ln}(4)$ \\
\hline & Phylloscopus collybita (chiffchaff) & 1 & 0 & 0 & 0 & \\
\hline & Phylloscopus sibilatrix (wood warbler) & 5 & 1 & 0 & 1 & $U(1)$ \\
\hline & Sylvia melanocephala (sardinian warbler) & 15 & 0 & 0 & 0 & \\
\hline & Sylvia communis (whitethroat) & 8 & 1 & 0 & 1 & $L(1)$ \\
\hline & Sylvia cantillans (subalpine warbler) & 40 & 14 & 2 & 12 & $\operatorname{Ln}(10) ; \operatorname{MdV}(4)$ \\
\hline & Cettia cetti (cetti's warbler) & 2 & 0 & 0 & 0 & \\
\hline \multirow[t]{3}{*}{ Muscicapidae } & Ficedula albicollis (collared flycatcher) & 1 & 0 & 0 & 0 & \\
\hline & Ficedula hypoleuca (pied flycatcher) & 6 & 0 & 0 & 0 & \\
\hline & Muscicapa striata (spotted flycatcher) & 51 & 13 & 10 & 3 & MdV (2); U (11) \\
\hline \multirow[t]{6}{*}{ Turdidae } & Phoenicurus phoenicurus (redstart) & 12 & 4 & 4 & 0 & L (1); Ln (3) \\
\hline & Turdus philomelos (song thrush) & 1 & 0 & 0 & 0 & \\
\hline & Erithacus rubecula (robin) & 1 & 1 & 1 & 0 & $\operatorname{Ln}(1)$ \\
\hline & Luscinia megarhynchos (nightingale) & 4 & 1 & 1 & 0 & $\operatorname{MdV}(1)$ \\
\hline & Monticola solitarius (blue rock-thrush) & 1 & 1 & 0 & 1 & $\operatorname{Ln}(1)$ \\
\hline & Saxicola rubetra (winchat) & 23 & 9 & 7 & 2 & L (7); U (2) \\
\hline Hirundinidae & Hirundo rustica (swallow) & 12 & 2 & 2 & 0 & $\operatorname{Ln}(2)$ \\
\hline \multirow[t]{2}{*}{ Passeridae } & Passer montanus (tree sparrow) & 1 & 0 & 0 & 0 & \\
\hline & Passer hispaniolensis (Spanish sparrow) & 8 & 4 & 3 & 1 & $\operatorname{Ln}(3) ; \operatorname{MdV}(1)$ \\
\hline Oriolidae & Oriolus oriolus (golden oriole) & 3 & 0 & 0 & 0 & \\
\hline Fringillidae & Carduelis cannabina (linnet) & 2 & 0 & 0 & 0 & \\
\hline Laniidae & Lanius senator (woodchat shrike) & 2 & 0 & 0 & 0 & \\
\hline Motacillidae & Anthus trivialis (tree pipit) & 2 & 0 & 0 & 0 & \\
\hline Paridae & Parus major (great tit) & 2 & 1 & 1 & 0 & $\operatorname{MdV}(1)$ \\
\hline Total & & 349 & $114(32.66 \%)$ & 68 & 46 & L (19); Ln (31); MdV (18); U (46) \\
\hline
\end{tabular}

a. The birds were captured by means of a Mist-nets with four shelf-nets (100 $\mathrm{m}$ in length) placed in the proximity of the woody areas in each site of ringing and treated following the instructions of the 'Istituto Superiore per la Protezione e la Ricerca Ambientale' (ISPRA). All birds were quickly ringed, identified at species level by phenotypic analysis (Mullarney et al., 1999) and soon after ringing the bird cloacae were examined for yeast presence following the methodology of Francesca and colleagues (2010).

b. SFA, subcutaneous fat amount.

c. L, Lampedusa; Ln, Linosa; MdV, Mazara del Vallo; U, Ustica.

warbler and subalpine warbler were the richer sources of fungal biodiversity. However, some WA yeasts, such as $S$. cerevisiae, the most important species in winemaking (Fleet, 2003), were similarly distributed among garden warbler, icterine warbler, redstar, whitethroat, subalpine warbler and winchat, while seven isolates were collected from spotted flycatcher.

\section{Wine-related yeasts}

The $58.40 \%$ of total yeasts and the majority of WA yeasts $(63.89 \%)$ were isolated from birds with an SFA value comprised between zero and one (Table 1). Some species as $D$. hansenii, M. pulcherrima and $R$. mucilaginosa were obtained only from birds with 0-1 SFA. Except for $H$. guilliermondii (45.45\%), the most abundant WA yeast species, such as A. pullulans $(66.66 \%)$ and S. cer- evisiae $(66.67 \%)$, were mainly collected from birds with low SFA. The species $P$. kudriavzevii and $P$. terricola are also considered WA.

To our knowledge, this research represents the first report on the isolation and characterization of WA yeasts carried by birds during migration and provides additional elements needing to be analysed when a strain is defined as autochthonous. It is already known that some insects (Drosophila, Apis and Vespa) may carry microorganisms, yeasts included, on their bodies (Snowdon and Cliver, 1996) and their gut (Ricci et al., 2011), but their contribution to the spreading of yeasts is within short distances.

In this study, a new finding deepens the knowledge about the environmental distribution of $S$. cerevisiae. Besides the fact that birds were analysed soon after landing, the sites of Lampedusa is not typically character- 


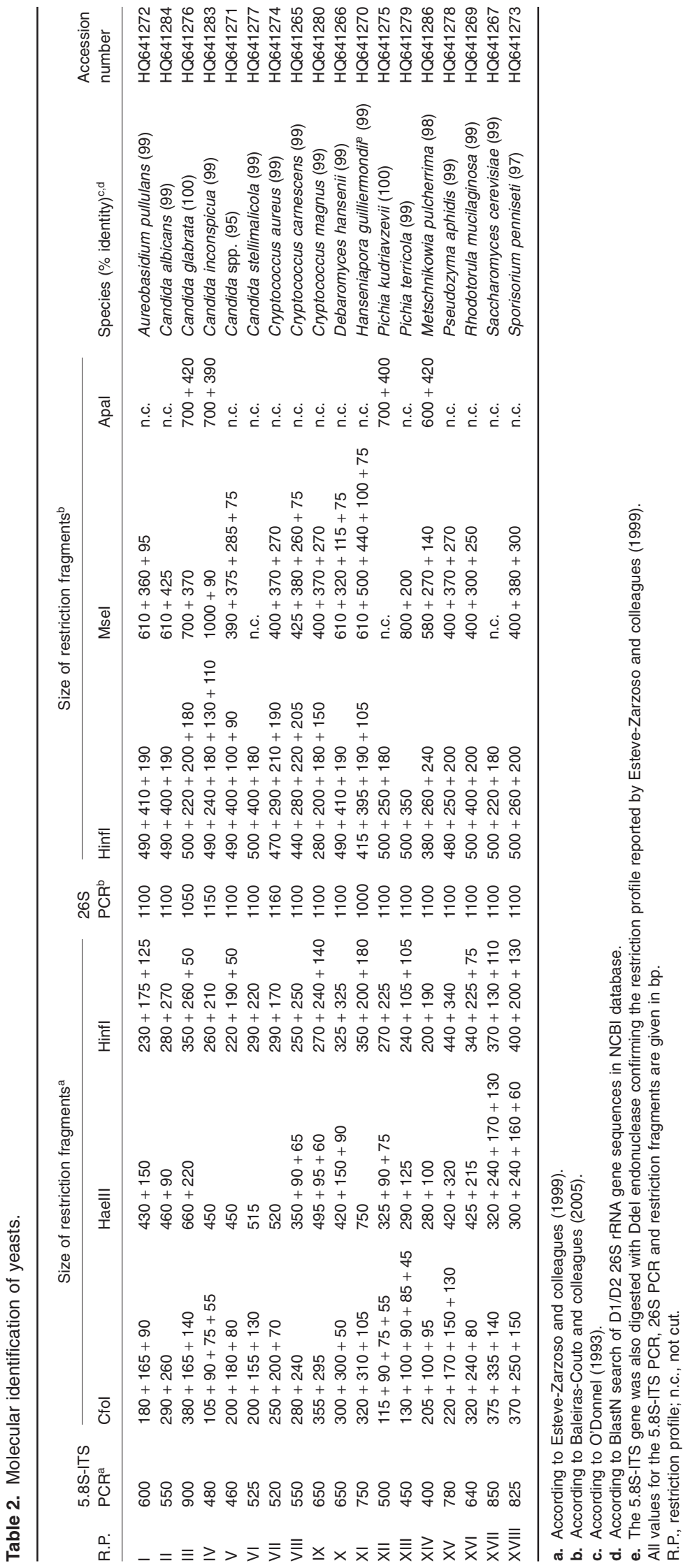




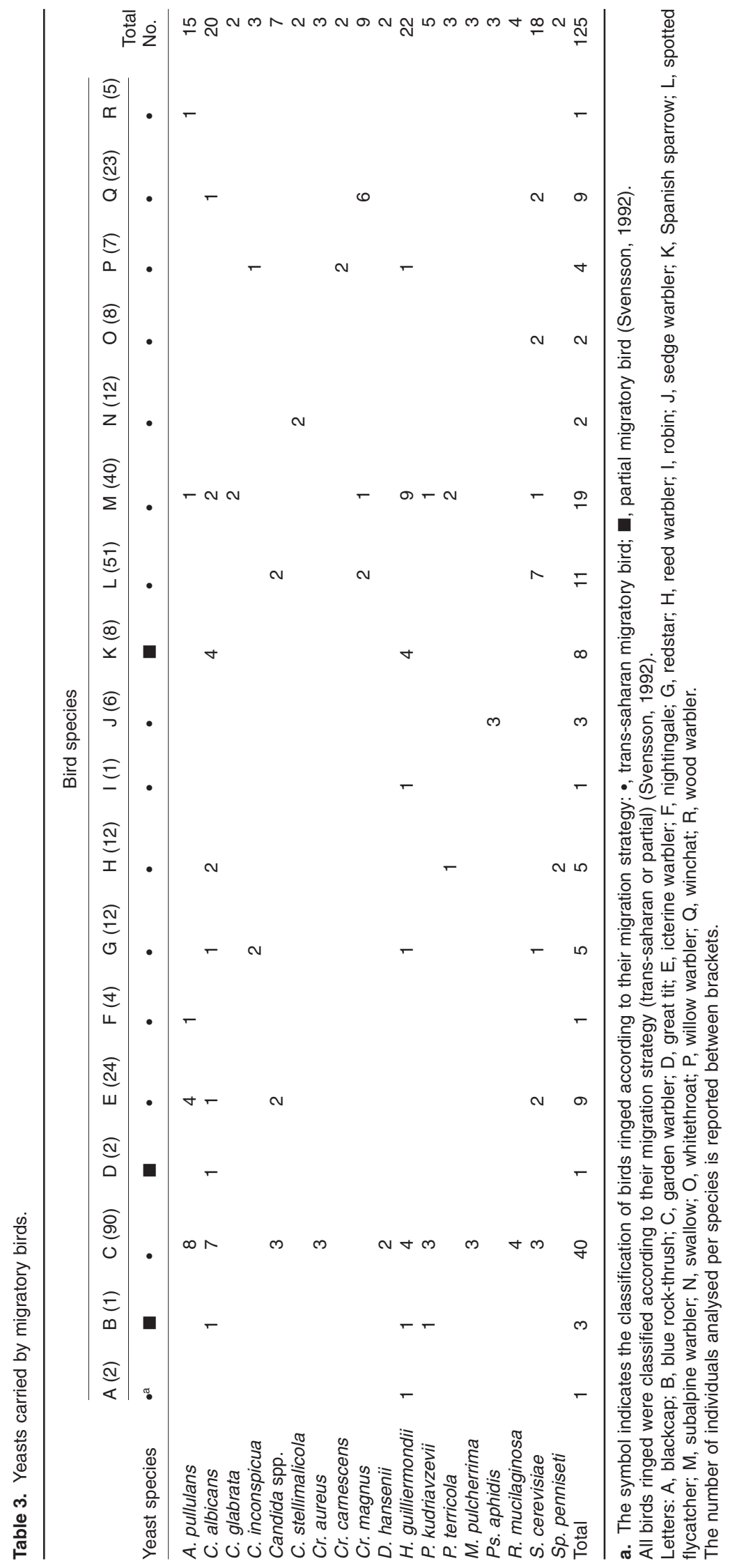


Table 4. Typing of Saccharomyces cerevisiae isolates.

\begin{tabular}{|c|c|c|c|c|c|c|c|c|}
\hline \multirow[b]{3}{*}{ Isolate code } & \multirow[b]{3}{*}{ Isolation source (bird code) } & \multirow[b]{3}{*}{$\mathrm{SFA}^{\mathrm{a}}$} & \multirow[b]{3}{*}{ Ringing site ${ }^{b}$} & \multicolumn{5}{|c|}{ Patterns } \\
\hline & & & & \multirow[b]{2}{*}{$\begin{array}{l}\text { Interdelta } \\
\text { analysis }^{c}\end{array}$} & \multirow[b]{2}{*}{$\begin{array}{l}\text { Microsatellite } \\
\text { multiplex PCR }\end{array}$} & \multicolumn{3}{|c|}{ Minisatellite analysis ${ }^{e}$} \\
\hline & & & & & & aga1 & sed 1 & dan4 \\
\hline ULSc24 & Icterine warbler (br1) & 1 & $\mathrm{~L}$ & Int1 & Mul1 & Mina1 & Mins1 & Mind1 \\
\hline ULSc26 & Icterine warbler (br2) & 1 & $\mathrm{~L}$ & Int1 & Mul1 & Mina1 & Mins1 & Mind1 \\
\hline ULSc28 & Whinchat (br3) & 1 & $\mathrm{~L}$ & Int1 & Mul1 & Mina1 & Mins1 & Mind1 \\
\hline ULSc29 & Whinchat (br3) & 2 & $\mathrm{~L}$ & Int2 & Mul2 & Mina2 & Mins2 & Mind2 \\
\hline ULSc30 & Whitetroat (br4) & 2 & $\mathrm{~L}$ & Int1 & Mul1 & Mina1 & Mins1 & Mind1 \\
\hline ULSc31 & Whitetroat (br5) & 2 & L & Int1 & Mul1 & Mina1 & Mins1 & Mind1 \\
\hline ULSc32 & Redstar (br6) & 1 & $\mathrm{~L}$ & Int1 & Mul1 & Mina1 & Mins1 & Mind1 \\
\hline ULSc37 & Garden warbler (br7) & 3 & $\mathrm{~L}$ & Int1 & Mul1 & Mina1 & Mins1 & Mind1 \\
\hline ULSc139 & Garden warbler (br8) & 2 & $\mathrm{U}$ & Int3 & Mul3 & Mina3 & Mins1 & Mind1 \\
\hline ULSc140 & Garden warbler (br9) & 2 & U & Int3 & Mul3 & Mina3 & Mins1 & Mind1 \\
\hline ULSc144 & Spotted flycatcher (br10) & 0 & $\mathrm{U}$ & Int3 & Mul3 & Mina3 & Mins1 & Mind1 \\
\hline ULSc145 & Spotted flycatcher (br11) & 0 & $\mathrm{U}$ & Int3 & Mul3 & Mina3 & Mins1 & Mind1 \\
\hline ULSc146 & Spotted flycatcher (br12) & 1 & U & Int3 & Mul3 & Mina3 & Mins1 & Mind1 \\
\hline ULSc148 & Spotted flycatcher (br13) & 1 & $\mathrm{U}$ & Int3 & Mul3 & Mina3 & Mins1 & Mind1 \\
\hline ULSc186 & Spotted flycatcher (br14) & 1 & $\mathrm{U}$ & Int3 & Mul3 & Mina3 & Mins1 & Mind1 \\
\hline ULSc326 & Spotted flycatcher (br15) & 1 & MdV & Int4 & Mul4 & Mina4 & Mins3 & Mind3 \\
\hline ULSc338 & Spotted flycatcher (br16) & 1 & $\mathrm{U}$ & Int5 & Mul5 & Mina5 & Mins4 & Mind4 \\
\hline ULSc339 & Subalpine warbler (br17) & 0 & $\mathrm{~L}$ & Int6 & Mul6 & Mina6 & Mins5 & Mind5 \\
\hline \multicolumn{4}{|c|}{ Total of different patterns } & 6 & 6 & 6 & 5 & 5 \\
\hline
\end{tabular}

a. SFA, subcutaneous fat amount.

b. L, Lampedusa; U, Ustica; MdV, Mazara del Vallo.

c. According to Legras and Karst (2003).

d. According to Vaudano and Garcia-Moruno (2008).

e. According to Marinangeli and colleagues (2004).

ized by wine production, and thus, the contamination of bird cloacae with local S. cerevisiae has to be excluded.

Due to their technological importance, the species S. cerevisiae was investigated at strain level. The 18 isolates (Table 3 ) belonging to this species were subjected to molecular typing by applying three techniques (interdelta analysis, minisatellite analysis based on the separate amplification of three genes and microsatellite multiplex PCR of polymorphic microsatellite loci); the corresponding patterns are reported in Table 4. The 18 isolates were allotted into six strains. The strain ULSc326, isolated from Mazara del Vallo site, was characterized by a profile not found for the other S. cerevisiae strains. The nine isolates obtained from Lampedusa island were grouped into three strains, while the eight isolates from Ustica island were divided into two strains. The patterns found for S. cerevisiae strains of Lampedusa were different from those found for $S$. cerevisiae strains of Ustica. These observations make plausible the statement that the leaving sites of birds landed at Ustica were different from those landed at Lampedusa, and it is also acceptable to state that the birds bringing S. cerevisiae with the same pattern profiles were originating from the same area. This affirmation is possible because a single bird (stonechat), captured in Lampedusa, brought two distinct strains.

\section{Non-wine-related yeasts}

The $58.40 \%$ of non-WA yeasts was obtained from birds with 0-1 SFA. Candida inconspicua and C. glabrata have been already isolated from birds (Cafarchia et al., 2006; Lord et al., 2010). Candida inconspicua has been detected in the oenological environment as contaminant of grape must (Le Roux et al., 1973), while C. stellimalicola has been isolated only once during the fermentation of grape must (Ocón et al., 2010). Few studies reported Cryptococcus spp. as occasional contaminants of grapes (Prakitchaiwattana et al., 2004; Li et al., 2010), barrel surfaces before wine contact (Renouf et al., 2006) and corks (Fleet, 2003). It is clear that these species have no role in winemaking processes for their sporadic isolation. Candida albicans, Pseudozyma aphydis and Sporisorium penniseti had never been reported to be isolated from wine environments.

\section{Persistence tests}

From the persistence tests performed in this study on birds, it was calculated an average timing for yeast dissemination by birds that is reasonably around $12 \mathrm{~h}$ from ingestion. The S. cerevisiae strain GR1, introduced in three robins through feeding, was isolated from bird mouths until $6 \mathrm{~h}$ after inoculation, as showed by inter- 
delta analysis. In the same period, the isolation of this strain from cloacae was negative. The test became positive for GR1 strain presence in cloacae after $12 \mathrm{~h}$. In the next monitoring steps, the strain inoculated was no more detected, neither from mouths nor from cloacae. The results were identical for all three birds employed in the test. From these results, it can be asserted that the permanence of a given $S$. cerevisiae strain in birds lasts no longer than $12 \mathrm{~h}$. Thus, the dissemination of yeasts by birds is supposed to be possible a few hours after ingestion and up to $12 \mathrm{~h}$. This interval is enough to cover a distance of approximately 300-350 km (Moreau, 1961 ; 1972) and it is compatible with a no-stop flight. In fact, most of the birds positive for yeast isolation were characterized by a low SFA (comprised between 0 and 1). Furthermore, the persistence tests also demonstrated that $S$. cerevisiae survives the transit through the gastric apparatus of birds. However, in case of yeast strains able to colonize the intestinal tract of birds their release might be gradual and prolonged with the possibility to be disseminated in a wider area than that covered in $12 \mathrm{~h}$.

For some authors, the autochthonous yeasts are linked to vineyard and/or cellar habitat in a given area (Lopes et al., 2002; Schuller et al., 2005), and for this reason, they are found in consecutive years (Torija et al., 2001; Schuller et al., 2005). All this statements support the idea of 'terroir', which is defined as an ecosystem in which the vine interacts with the environmental factors (soil and climate) affecting the quality and typicality of the wine produced in a particular location (Terroir Viticoles, 2006). From this perspective, the dissemination of yeasts by migratory birds might contribute to explain the differences observed in vineyards examined in consecutive years (Schuller et al., 2005; Valero et al., 2005).

\section{Conclusions}

Data showed by this study demonstrated yeasts may be disseminated by migrating birds. In particular, winerelated yeasts are vehiculated in active state during bird movements. The last finding highlights the needing of better analysing the concept of 'autochthonous' yeasts in winemaking, since yeasts selected for the oenological aptitudes in a given environment may not be indigenous.

\section{Acknowledgements}

The authors are grateful to Professor Bruno Massa, Dr Paolo Lucido, Dr Ciro Sannino and Antonio Alfonzo for their help with analysis and interpretation of data. Dr Stefania D'Angelo and the staff of Riserva Naturale Integrale Lago Preola and
Gorghi Tondi (Mazara del Vallo, TP, Italy) are also thanked for their supervision during bird ringing.

\section{References}

Baleiras-Couto, M.M., Reizinho, R.G., and Duarte, F.L. (2005) Partial 26S rDNA restriction analysis as a tool to characterize non-Saccharomyces yeasts present during red wine fermentations. Int J Food Microbiol 102: 49-56.

Burton, N.H.K., Rehfisch, M.M., Clark, N.A., and Dodd, S.G. (2006) Impacts of sudden winter habitat loss on the body condition and survival of redshank Tringa tetanus. J Appl Ecol 43: 464-473.

Cafarchia, C., Camarda, A., and Romito, D. (2006) Occurrence of yeasts in cloacae of migratory birds. Mycopathologia 161: 229-234.

Esteve-Zarzoso, B., Belloch, C., Uruburu, F., and Querol, A. (1999) Identification of yeasts by RFLP analysis of the $5.8 S$ rRNA gene and the two ribosomal internal transcribed spacers. Int J Syst Bacteriol 49: 32-337.

Fernandez-Espinar, M.T., Esteve-Zarzoso, B., Querol, A., and Barrio, E. (2000) RFLP analysis of the ribosomal transcribed spacers and the 5.8S rRNA gene region of the genus Saccharomyces: a fast method for species identification and the differentiation of flor yeasts. Antonie Leeuwenhoek 78: 87-97.

Fleet, G.H. (2003) Yeast interactions and wine flavour. Int $J$ Food Microbiol 86: 11-22.

Francesca, N., Chiurazzi, M., Romano, R., Aponte, M., Settanni, L., and Moschetti, G. (2010) Indigenous yeast communities in the environment of 'Rovello bianco' grape variety and their use in commercial white wine fermentation. World J Microb Biotechnol 26: 337-351.

Goddard, M.R., Anfang, N., Tang, R., Gardner, R.C., and Jun, C. (2010) A distinct population of Saccharomyces cerevisiae in New Zealand: evidence for local dispersal by insects and human-aided global dispersal in oak barrels. Environ Microbiol 12: 63-73.

Gonzalez-Pombo, P., Perez, G., Carrau, F., Guisan, J.M., Batista-Viera, F., and Brena, B.M. (2008) One-step purification and characterization of an intracellular b-glucosidase from Metschnikowia pulcherrima. Biotechnol Lett 30: 1469-1475.

Goymann, W., Spina, F., Ferri, A., and Fusani, L. (2010) Body fat influences departure from stopover sites in migratory birds: evidence from whole island telemetry. Biol Lett 6: 478-481.

Kaiser, A. (1993) A new multi-category classification of subcutaneous fat deposits of songbirds. J Field Ornithol 64: 246-255.

Kurtzman, C.P., and Robnett, C.J. (2003) Phylogenetic relationships among yeast of the 'Saccharomyces complex' determined from multigene sequence analyses. FEMS Yeast Res 3: 417-432.

Le Roux, G., Eschenbruch, R., and De Bruin, S.I. (1973) The microbiology of South African wine-making. Part VIII. The microflora of healthy and Botrytis cinerea infected grapes. Phytophylactica 5: 51-54.

Legras, J.L., and Karst, F. (2003) Optimisation of interdelta analysis for Saccharomyces cerevisiae strain characterization. FEMS Microbiol Lett 221: 249-255. 
Li, S.-S., Cheng, C., Li, Z., Chen, J.Y., Yan, B., Han, B.Z., and Reeves, M. (2010) Yeast species associated with wine grapes in China. Int J F Microb 138: 85-90.

Lopes, C.A., van Broock, M., Querol, A., and Caballero, A.C. (2002) Saccharomyces cerevisiae wine yeast populations in a cold region in Argentinean Patagonia. A study at different fermentation scales. J Appl Microbiol 93: 608615.

Lord, A.T.K., Mohandas, K., Somanath, S., and Ambu, S. (2010) Multidrug resistant yeasts in synanthropic wild birds. An Clin Microb Antim 9: 11.

Loureiro, V., and Malfeito-Ferreira, M. (2003) Spoilage yeasts in the wine industry. Int J Food Microbiol 86: 23-50.

Marinangeli, P., Angelozzi, D., Ciani, M., Clementi, F., and Mannazzu, I. (2004) Minisatellites in Saccharomyces cerevisiae genes encoding cell wall proteins: a new way towards wine strain characterisation. FEMS Yeast Res 4: 427-435.

Maul, J.D., Gandhi, J.P., and Farris, J.L. (2005) Communitylevel physiological profiles of cloacal microbes in songbirds (order: Passeriformes): variation due to host species, host diet, and habitat. Microb Ecol 50: 19-28.

Moreau, R.E. (1961) Problems of Mediterranean-Saharan migration. Ibis 103a: 373-427.

Moreau, R.E. (1972) The Palaearctic-African Bird Migration Systems. London, UK and New York, USA: Academic Press.

Moreira, N., Mendes, F., Guedes de Pinho, P., Hogg, T., and Vasconcelos, I. (2008) Heavy sulphur compounds, higher alcohols and esters production profile of Hanseniaspora uvarum and Hanseniaspora guilliermondii grown as pure and mixed cultures in grape must. Int J Food Microbiol 124: 231-238.

Mortimer, R.K. (2000) Evolution and variation of the yeast (Saccharomyces) genome. Genome Res 10: 403409.

Mortimer, R.K., and Polsinelli, M. (1999) On the origin of wine yeast. Res Microbiol 150: 199-204.

Mullarney, K., Svensson, L., Zetterstrom, D., and Grant, P. (1999) Bird Guide. London, UK: Harper Collins Publisher.

Naumov, G.I. (1996) Genetic identification of biological species in the Saccharomyces sensu stricto complex. $J$ Ind Microbiol 17: 295-302.

Nuttall, P.A. (1997) Viruses, bacteria and fungi of birds. In Hosteparasite Evolution. Clayton, D.H., and Moore, J. (eds). Oxford, UK: University Press, pp. 271-302.

O'Donnel, K. (1993) Fusarium and its near relatives. In The Fungal Anamorph: Mitotic, Meiotic and Pleomorphic Speciation in Fungal Systematics. Reynolds, D.R., and Taylor, J.W. (eds). Wallingford, UK: CAB International, pp. 225233.

Ocón, E., Gutiérrez, A.R., Garijo, P., Tenorio, C., López, I., and Santamaría, P. (2010) Quantitative and qualitative analysis of non-Saccharomyces yeasts in spontaneous alcoholic fermentations. Eur Food Res Technol 230: 885891.

Omenn, G.S. (2010) Evolution and public health. Proc Nat/ Acad Sci USA 107 (Suppl. 1): 1702-1709.

Prakitchaiwattana, C.J., Fleet, G.H., and Heard, G.M. (2004) Application and evaluation of denaturing gradient gel electrophoresis to analyse the yeast ecology of wine grapes. FEMS Yeast Res 4: 856-877.

Renouf, V., Perello, M.C., Strehaiano, P., and Lonvaud-Funel, A. (2006) Global survey of the microbial ecosystem during alcoholic fermentation in winemaking. Journal International des Sciences de La Vigne et du Vin 40: 101-116.

Ricci, I., Damiani, C., Scuppa, P., Mosca, M., Crotti, E., Rossi, P., et al. (2011) The yeast Wickerhamomyces anomalus (Pichia anomala) inhabits the midgut and reproductive system of the Asian malaria vector Anopheles stephensi. Environ Microbiol 13: 911-921.

Schuller, D., Alves, H., Dequin, S., and Casal, M. (2005) Ecological survey of Saccharomyces strains from vineyards in the Vinho Verde Region of Portugal. FEMS Microbiol Ecol 51: 167-177.

Silvanose, C.D., Bailey, T.A., Naldo, J.L., and Howlett, J.C. (2001) Bacterial flora of the conjunctiva and nasal cavity in normal and diseased captive bustards. Avian Dis 42: 447451.

Snow, D.W., and Perrins, C.M. (1998) The Birds of the Western Palearctic: Concise Edition. Oxford, UK: Oxford University Press.

Snowdon, J.A., and Cliver, D.O. (1996) Microorganisms in honey. Int J Food Microbiol 31: 1-26.

Solieri, L., Cassanelli, S., and Giudici, P. (2007) A new putative Zygosaccharomyces yeast species isolated from traditional balsamic vinegar. Yeast 24: 403-417.

Svensson, L. (1992) Identification Guide to European Passerines. Stockholm, Sweden: British Trust for Ornithology.

Terroir Viticoles (2006) VI International Terroir Congress, Montpellier.

Tofalo, R., Chaves-López, C., Di Fabio, F., Schirone, M., Felis, G.E., Torriani, S., et al. (2009) Molecular identification and osmotolerant profile of wine yeasts that ferment a high sugar grape must. Int J Food Microbiol 130: 179-187.

Torija, M.J., Rozes, N., Poblet, M., Guillamon, J.M., and Mas, A. (2001) Yeast population dynamics in spontaneous fermentations: comparison between two different wineproducing areas over a period of three years. Antonie Leeuwenhoek 79: 345-352.

Valero, E., Schuller, D., Cambon, B., Casal, M., and Dequin, S. (2005) Dissemination and survival of commercial wine yeast in the vineyard: a large-scale, three-years study. FEMS Yeast Res 5: 959-969.

Vaudano, E., and Garcia-Moruno, E. (2008) Discrimination of Saccharomyces cerevisiae wine strains using microsatellite multiplex PCR and band pattern analysis. Food Microbiol 25: 56-64. 